\title{
Risk Factors for Peripartum Mastitis in Pasture-Grazed Dairy Heifers
}

\author{
C. W. R. Compton,${ }^{\star 1}$ C. Heuer, $\dagger$ K. Parker, ${ }^{\star}$ and S. McDougall ${ }^{\star}$ \\ ${ }^{*}$ Animal Health Centre, PO Box 21, Morrinsville 3340, New Zealand \\ †Epicentre, Massey University, Private Bag 11-222, Palmerston North 4442, New Zealand
}

\begin{abstract}
A longitudinal observational field study was conducted using 708 heifers in 30 spring-calving dairy herds in the Waikato region of New Zealand. The aim of the study was to investigate risk factors for subclinical and clinical mastitis (CM) in the peripartum period using path analysis methods and to find the factors most important at the population level as a basis for potential control programs. Body condition and udder hygiene scores, blood samples, and quarter mammary secretion samples for bacteriology were collected approximately $3 \mathrm{wk}$ before the planned start of the seasonal calving period and again within $5 \mathrm{~d}$ following calving. Additionally, milk samples were collected from quarters diagnosed with $\mathrm{CM}$ within $14 \mathrm{~d}$ of calving. Significant risk factors for subclinical mastitis postcalving were precalving subclinical mastitis (3.32 incidence risk ratio; IRR), low minimum teat height above the ground (1.32 IRR), and unhygienic udder postcalving (1.32 IRR). Significant risk factors for clinical mastitis postcalving were precalving subclinical mastitis (2.14 IRR), Friesian breed (1.94 IRR), low minimum teat height above the ground (2.05 IRR), udder edema (1.81 IRR), and low postcalving nonesterified fatty acid serum concentration (1.55 IRR). Control of precalving subclinical mastitis and udder edema by producers, and enhancement of breed immunity by geneticists were important factors at a population level, and hence, are likely the most rewarding areas to target in any heifer mastitis management program.
\end{abstract}

Key words: mastitis, heifer, peripartum, risk factor

\section{INTRODUCTION}

Mastitis in dairy cows is common and imposes significant economic costs on producers. The average cumulative incidence of clinical mastitis $(\mathbf{C M})$ was $9.9 \%$ in 38 commercial New Zealand herds in early lactation (McDougall, 1998). Both CM and subclinical mastitis

Received December 21, 2006.

Accepted May 16, 2007.

${ }^{1}$ Corresponding author: ccompton@ahc.co.nz in periparturient heifers are common (Trinidad et al., 1990) and CM occurs at higher incidence rates than in greater parity cows (Barkema et al., 1998). Different management and physiological status of heifers compared with cows likely contribute to the difference in mastitis incidence observed. Factors at the heifer and quarter level that increase the risk of peripartum CM and subclinical mastitis in international studies include Friesian breed (Myllys and Rautala, 1995), age at calving (de Vliegher et al., 2004), dystocia (Barnouin and Chassagne, 2001), increased milk-out speed (Slettbakk et al., 1990), milk leakage at calving (Waage et al., 2001), teat and udder edema (Slettbakk et al., 1995; Waage et al., 2001), blood in milk (Waage et al., 2001), decreasing teat-end to floor distance (Slettbakk et al., 1995), and precalving quarter subclinical mastitis (Myllys, 1995; Aarestrup and Jensen, 1997). Recent studies investigated associations between physiological changes in cows in the peripartum period, such as high serum ketone (BHBA) levels and negative energy balance, which are associated with depressed immune function and increased susceptibility to mastitis (Suriyasathaporn et al., 2000). Yet, the seasonal calving and pasture-grazing management systems commonly used in New Zealand may result in different risk factors and different relative importance to those from confined, nongrazed cattle.

Few preventive programs are available specifically aimed at controlling mastitis in peripartum dairy heifers. The use of prepartum intramammary antibiotics to treat and prevent IMI in primigravid heifers was reported with varying rates of efficacy (Borm et al., 2006) and there may be increased risk of antibiotic residues in milk and increased consumer concerns about prophylactic use of antibiotics. Additionally, use of an artificial internal teat sealant reduced mastitis at calving (Parker et al., 2007).

The main aim of this study was to determine risk factors for peripartum subclinical mastitis and CM in pasture-grazed dairy heifers, at both the quarter and heifer level, and describe them using path analysis methods. A secondary aim was to estimate the proportion of cases in the population attributable to the identified risk factors for subclinical mastitis and CM, and 
thereby determine factors for which effective control would provide the greatest population benefit.

\section{MATERIALS AND METHODS}

\section{Study Population, Data Collection, and Variable Definition}

Thirty spring-calving dairy herds were purposefully selected for a prospective observational study commencing in June 2004. A systematic random selection of heifers in each herd was enrolled on one calendar date, approximately $3 \mathrm{wk}$ before the planned starting date of the calving period. A total of 708 heifers was enrolled. Heifer breeds were Friesian ( $\mathrm{n}=291)$, Jersey $(\mathrm{n}=214)$, and other (predominantly Friesian-Jersey crossbreed, $\mathrm{n}=203$ ). Enrolled heifers were managed with the others of the same parity group until all heifers had calved. The diet was predominantly rye grass (Lolium perenne) and white clover (Trifolium repens) fed in situ with a new area of pasture being offered daily and with small amounts ( 1 to $2 \mathrm{~kg}$ of DM) of hay and pasture silage fed on the grazing area.

At the time of enrollment, a single sample of mammary secretion was collected from each gland for bacteriologic examination following aseptic preparation of the teat end. A commercial iodine-based teat antiseptic with $0.5 \%$ available iodine was applied to the teats immediately after sampling. Standard methods for microbiology, diagnosis of IMI, and categorization of results were used (Hogan et al., 1999). Ten-microliter milk samples were streaked onto a quarter plate of $5 \%$ sheep blood, $0.1 \%$ esculin agar (Fort Richard, Auckland, New Zealand) using a sterile disposable loop. Plates were incubated at $37^{\circ} \mathrm{C}$ for $48 \mathrm{~h}$ before reading results. All gram-positive, catalase-negative cocci were categorized as streptococci and further speciated by their esculin reaction and CAMP (Christie, Atkins, Munch-Peterson) test results. Gram-positive, catalase-positive cocci were coagulase tested using a commercial kit (BBL Staphyloslide Latex Test, Becton and Dickinson, Sparks, MD) and categorized as either CNS or coagulase-positive (assumed Staph. aureus). Gram-negative rods that could be identified with the basic biochemical tests available to this laboratory (lactose, oxidase, triple sugar iron, Simmons citrate, and motility) were identified and recorded, and unidentified organisms were recorded as gram-negative rods. Gram-positive rods that could be identified with simple procedures were identified and recorded (e.g., Corynebacterium spp.). Bacillus organisms were identified by morphology only and recorded as Bacillus spp., and any unidentified organisms in this group were recorded as gram-positive rods. The number of colonies of each colony type was counted (up to a maximum of 50). Samples with more than 2 colony types were defined as contaminated. Samples from which fewer than 3 colonies of any 1 type of organism were found were recorded as "no growth," except for Staph. aureus where $\geq 1$ colony was recorded as an isolate. Where duplicate samples were collected, both samples were required to have $>2$ colonies of the same bacterial species for the glands to be defined as infected. If 1 of the duplicate samples was contaminated, the results from the uncontaminated duplicate alone were used to diagnose infection. Bacterial isolates were categorized as either major or minor pathogens. Bacterial species classified as major pathogens were Enterococcus spp., Escherichia coli, Klebsiella spp., Pasteurella spp., Proteus spp., Pseudomonas spp., Staph. aureus, Streptococcus agalactiae, Streptococcus dysgalactiae, and Streptococcus uberis. Minor pathogens were CNS, Corynebacterium spp., undifferentiated gram-negative rods, undifferentiated gram-positive rods, and yeasts. When a quarter had both a major and a minor pathogen isolated at the same time, the quarter was defined as infected with the major pathogen for that sampling occasion. Milk samples that were either contaminated or not collected were assigned missing values for analysis.

Additionally at the time of enrollment, duplicate blood samples were collected from the tail vein. The degree of udder contamination was assessed using the hygiene scoring system of Schreiner and Ruegg (2002): 1 = complete or almost complete freedom from dirt; $2=$ slightly dirty; $3=$ mostly covered in dirt; and $4=$ completely covered in dirt. Body condition score was assessed on a 1 to 10 scale with half score increments (Macdonald and Roche, 2004). The length of the tail of each heifer was recorded on an ordinal scale as $1=$ docked short $(<20 \mathrm{~cm}$ in total length); $2=$ docked medium length (20 to $40 \mathrm{~cm}$ total length); 3 = natural length, but with the twitch trimmed; and $4=$ natural length and untrimmed.

Duplicate milk samples were collected from all glands of each heifer and measurements recorded using the same methods within $5 \mathrm{~d}$ of calving during preplanned twice-weekly visits to the herds by trained technicians. If CM was diagnosed before a planned visit, duplicate milk samples were taken from all glands and measurements recorded by a trained technician and that heifer was not sampled again. Duplicate milk samples were collected from quarters with first cases of $\mathrm{CM}$ occurring after the preplanned 1 to $5 \mathrm{~d}$ period; that is, between 6 and $14 \mathrm{~d}$ of lactation. Measures recorded at the routine postcalving visit were udder hygiene and BCS, tail length, presence or absence of skin lesions on the barrel or orifice of each teat, minimum height of the front quarters above the floor of the milking parlor $(\mathrm{cm})$ measured using a flexible tape, presence or absence of udder 
Table 1. Abbreviations and definitions of variables used in null and final path models of risk factors for peripartum mastitis in pasturegrazed dairy heifers.

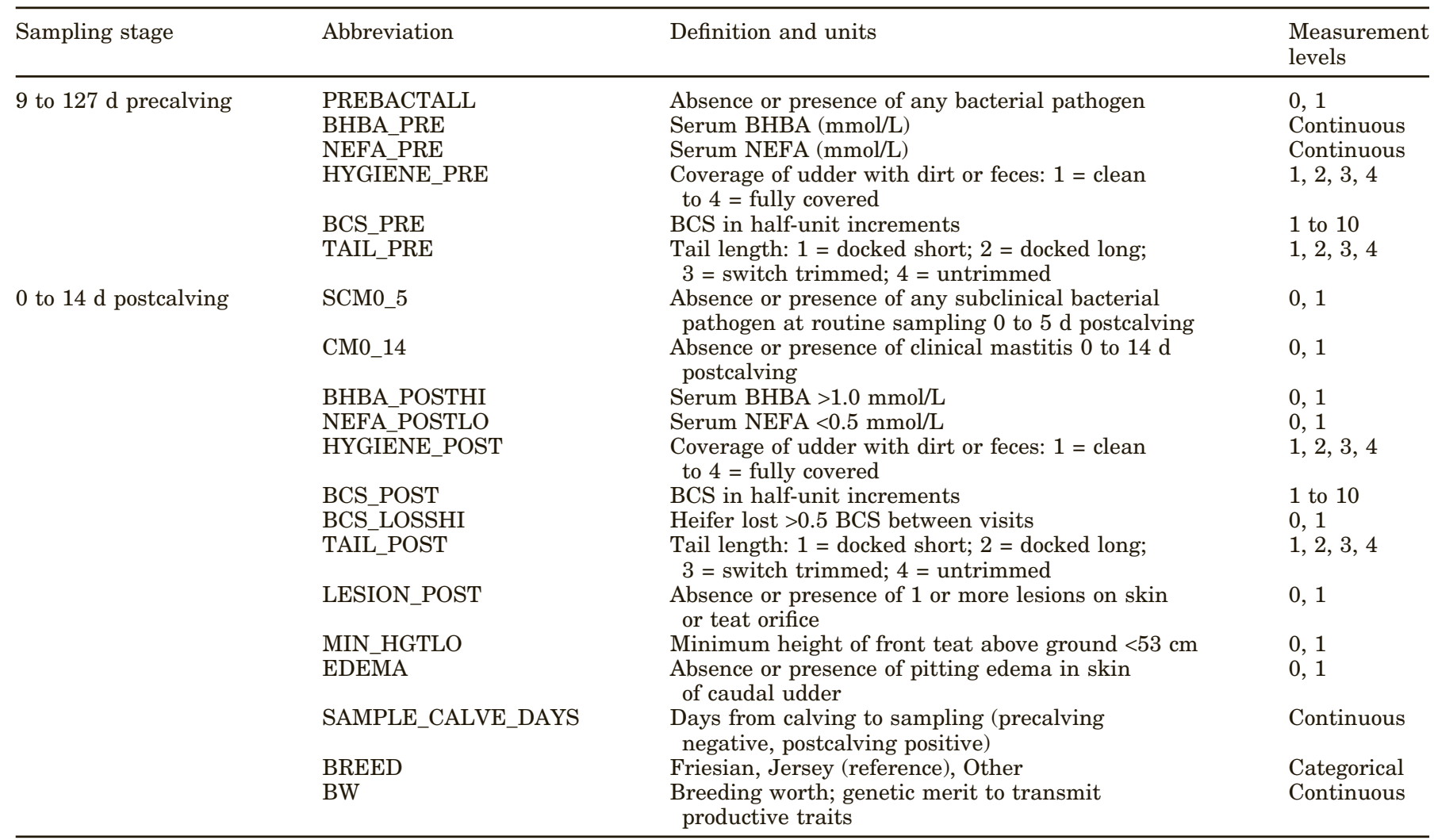

edema defined as presence or absence of a depression being present $>5 \mathrm{~s}$ after a digital depression was created in the middle of the rear of the udder, and abnormal placement or direction of teats defined as grossly abnormal position on udder or direction $>30^{\circ}$ beyond vertical. Duplicate blood samples were taken as before and held at room temperature for approximately $24 \mathrm{~h}$ before centrifugation at $1,500 \times g$ for $15 \mathrm{~min}$. The serum was stored at $-20^{\circ} \mathrm{C}$ before analysis of BHBA and NEFA concentrations (Alpha-Gribbles, Hamilton, New Zealand) using an Hitachi 717 Autoanalyzer at $30^{\circ} \mathrm{C}$ (interassay $\mathrm{CV}$ for $\mathrm{BHBA}=3 \%$ and for $\mathrm{NEFA}=5 \%$; intrassay $\mathrm{CV}$ for both analyses $=1 \%$ ).

Definitions of the variables considered for path analysis are shown in Table 1. Heifer data including breed, New Zealand EBV, calving date, and individual animal second monthly milk production records were obtained electronically from a national database (Livestock Improvement Corporation, Hamilton, New Zealand).

Clinical mastitis was diagnosed by herd owners based on detection of abnormal quarter secretions including clots or serum-like secretion, or presence of heat, swelling, or hardness of a quarter, or both. Subclinical mastitis was defined as isolation of bacteria from a milk sample in the absence of signs of CM. Intramammary infection was defined as isolation of bacteria from a milk sample, with or without signs of CM, and was used in descriptive analysis of the data, but not the risk factor path analysis.

\section{Data Analysis}

Many diseases of animals are multifactorial. These factors may be interrelated and operate in sequence or at various points in a causal pathway. Path analysis enables postulation of an ordering of causation among variables based on biological plausibility and temporal relationships, and estimates the association(s) between them. Path analysis methods are particularly appropriate for this study because of the temporal ordering of sampling and measurements.

Path analysis was undertaken using methods described by Curtis et al. (1988). Study outcomes were modeled at the quarter level because bacteriological results were available on this basis, and variables at the heifer level were included in a multilevel model. A postulated (null) path model (Figure 1) was formulated based on findings from other studies in the scientific literature, biological reasoning, or where there was an interest to test a specific hypothesis. Variables were 


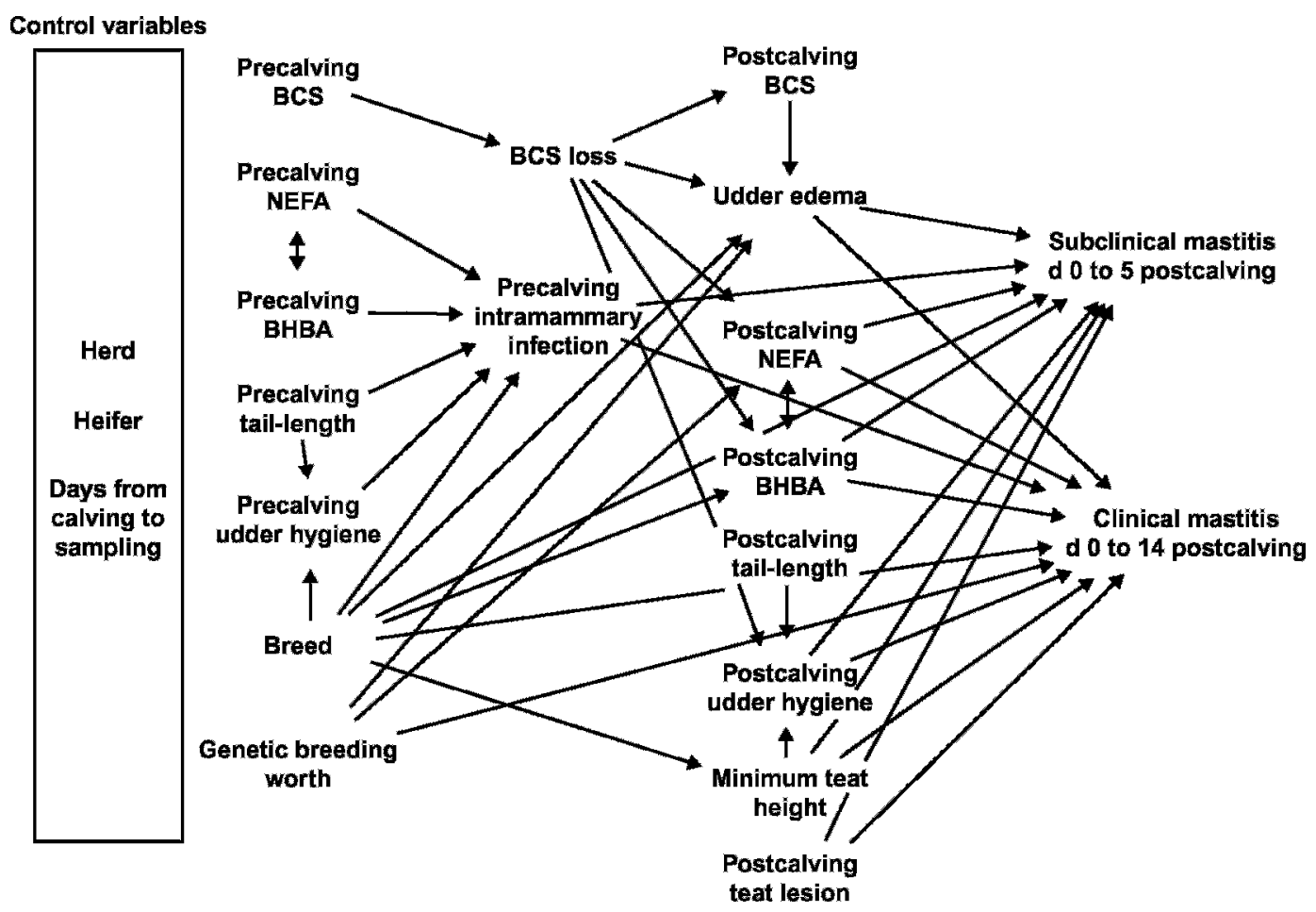

Figure 1. Null path model of postulated causal pathways between measured risk factors and subclinical and clinical mastitis in pasturegrazed New Zealand dairy heifers. Control variables (boxed) were included in regression models to control for their confounding effects.

connected with arrows that represent hypothesized correlation (double-headed arrows) or causation (singleheaded arrow from risk factor to effect). The path model should be read from left to right in the direction of causation and time-order. Feedback loops were not possible as disease could only occur once and the time order is from left to right. Exogenous variables (e.g., breed) were shown with no arrows leading to them and explanations for these were not sought. Control variables (herd, heifer, and days between sampling and calving) were placed in a box on the far left and included in all regression models to adjust for their potential confounding effects. Other variables are termed "endogenous," and the relationships between these were examined in the path analysis.

Data were of a hierarchical nature (quarters nested within heifers, in turn nested within herds), and observations within the lower 2 levels of measurement could not be considered independent. Correlation between outcomes needs to be accounted for in the analysis to avoid overly optimistic interpretations of $P$-values for associations and biased point estimates (Dohoo et al., 2003). To account for the correlation of subclinical mastitis and CM of quarters within heifer and heifer within herd, each model included random effects for both heifer and herd. The multilevel statistical model may be represented mathematically as

$$
\begin{gathered}
(\mathrm{g}) \mathbf{Y}_{\mathrm{ijk}}=\beta_{0}+\beta_{1} \mathbf{X}_{1}+\beta_{2} \mathbf{X}_{2}+\ldots \beta_{n} \mathbf{X}_{n} \\
+\boldsymbol{\mu}_{\text {heifer (j) }}+\boldsymbol{\mu}_{\text {herd (k) }}+\varepsilon_{\mathrm{ijk}}
\end{gathered}
$$

where (g) refers to the logit link function, $\mathbf{Y}_{\mathrm{ijk}}$ is the probability of the outcome variable on the logit scale, $\boldsymbol{\beta} \mathbf{s}$ are the model coefficients, $\mathbf{X}_{\mathbf{S}}$ are the variables included in the models, $j$ refers to the heifer, $k$ refers to the herd, and $i$ to the $i$ th quarter in the $j$ th heifer in the $k$ th herd, and the random effects are independent and normally distributed: $\boldsymbol{\mu}_{\text {heifer }(j)} \sim \mathrm{N}\left(0, \sigma_{\text {heifer }}^{2}\right)$, $\boldsymbol{\mu}_{\text {herd }}$ (k) $\sim \mathrm{N}\left(0, \sigma_{\text {herd }}^{2}\right), \varepsilon_{\mathrm{ijk}} \sim \mathrm{N}\left(0, \sigma^{2}\right)$.

Although heifers were selected at random within farm, this approach assumed that the 30 study farms were a reasonable representation of the population of farms.

Associations between variables were presented as incidence risk ratios (IRR) because they explain the multiplicative risk of an outcome for a given level of exposure compared with a reference level. Incidence risk ratio measures and confidence intervals (CI) are not obtainable directly from standard logistic regression models using the canonical logistic link, but were estimated from mixed logistic regression models using the "log" link (McNutt et al., 2003). Initially, unconditional (univariate) associations between outcome and explanatory variables were examined using crude risk 
ratios for categorical variables and univariate ordinary logistic regression for continuous variables. Statistical testing of the null path models was done using multivariable mixed logistic regression models fitted by penalized quasi-likelihood with random intercepts using the statistical software "R" ( $R$ Development Core Team, 2005). Each endogenous variable was regressed on all antecedent variables directly linked to it by hypothesized causal pathways in a backward stepwise method. Wald tests were used to assess the significance of terms in the model, and those with $P$-values $\leq 0.05$ were included. Confounding variables altering the coefficients of association $>10 \%$ were retained in the model even if not significant. First-order interaction terms were tested in the model in a forward stepwise manner using the same criteria. Finally, control variables (i.e., herd, heifer, and the interval from calving to sampling) were included in all models. Model residuals were inspected for unusual patterns. Data from a small number of measurements and samples were missing (maximum $=$ $6 \%$, Table 2); therefore, the sample size varied between models. Nonsignificant paths were removed from the null model to give paths and coefficients for a final model (Figure 2), which shows variables and pathways where significant direct effects were found or where confounding was considered important. The path coefficients represent the magnitude of the direct effect measured in units of IRR of a hypothesized causal factor on an outcome factor, when all other predictive factors in the model are held constant.

Population attributable fraction (PAF) is defined by Dohoo et al. (2003) as the proportion of disease in the whole population that is attributable to the exposure, and would be avoided if the exposure were removed, assuming a causal relationship between exposure and disease. Mathematically, it is expressed as

$$
P A F=\frac{p(E+)(R R-1)}{p(E+)(R R-1)+1}
$$

where $p(E+)$ is the prevalence of the exposure in the population, and $R R$ is the relative risk (or IRR). It is a useful measure to prioritize population health interventions, and is of most use when the factor of interest is clearly causally related to the outcome, and where the exposure is amenable to intervention. Point estimates and CI for PAF were estimated using the method of Greenland (2001), which uses adjusted risk ratios calculated from multivariable models and calculates CI using Wald estimates.

Data were recorded in an Access (Microsoft Corp., Redmond, WA) database. Statistical significance was declared for tests with $P$-values $\leq 0.05$, and CI for estimates were at the $95 \%$ level.

\section{RESULTS}

Precalving prevalence of quarter IMI with any pathogen was $18.5 \%$. Coagulase-negative staphylococci were the most prevalent pathogens isolated (13.5\%), and in decreasing proportion were Strep. uberis $(2.8 \%)$, other gram-negative bacteria $(0.5 \%)$, and Staph. aureus $(0.4 \%)$. Postcalving prevalence of IMI with any pathogen was $21.5 \%$. Streptococcus uberis was the most common pathogen postcalving (10.0\%), and in decreasing proportion were CNS (9.7\%), Staph. aureus (0.6\%), and E. coli $(0.5 \%)$. Clinical mastitis was diagnosed in $7.0 \%$ of quarters and $23.4 \%$ of heifers within $14 \mathrm{~d}$ following calving. Pathogens isolated from quarters diagnosed with CM were mainly Strep. uberis (64.4\%), with lesser percentages of CNS (7.7\%), E. coli (3.6\%), Strep. dysgalactiae $(3.1 \%)$, and Staph. aureus (2.6\%; Compton et al., 2007).

The variables used in the null and final models for path analysis, with their time of sampling and descriptive statistics, are presented in Table 2. Udder hygiene of heifers precalving was predominantly score 1 (55\%) and score $2(27 \%)$. Postcalving, score 2 udders were more prevalent (39\%), and "clean" (score 1) udders had declined in prevalence to $37 \%$. For paired records, udder hygiene score increased significantly from pre- to postcalving (difference $=17.9 \%$, CI of difference $=13.0$ to $22.8 \%$ ). Udder edema was commonly diagnosed in heifers postcalving (prevalence $=61 \%$ ), and its prevalence significantly declined with days postcalving $(P<0.01$, in regression models). Teat-end lesions were recorded in only $33(1 \%)$ of quarters within $5 \mathrm{~d}$ following calving and they were not significantly associated with either subclinical mastitis on d 0 to 5 postcalving (SCM0_5) or clinical mastitis on d 0 to 14 postcalving (CM0_14). Teat position was scored as abnormal in only 11 quarters $(0.3 \%)$, and was not considered in the analysis because of its very low prevalence. Tails of heifers precalving were mostly of their normal length (81\%), and only $4 \%$ had been docked short (Table 2). Within $5 \mathrm{~d}$ of calving, $63 \%$ of tails had been trimmed (score 3), and $10 \%$ had been docked short. Tail-length was not associated with udder hygiene score either pre- or postcalving. Median BCS precalving of heifers was 6 (range $=4.5$ to 8.0) and declined to 5.0 (range $=3.5$ to 6.5 ) postcalving. Serum BHBA concentrations precalving had a median of $0.7 \mathrm{mmol} / \mathrm{L}$, but $21 \%$ of heifers had concentrations $>1.0 \mathrm{mmol} / \mathrm{L}$. Serum NEFA concentrations at the same sampling time had a median and upper quartile of 0.39 and $0.56 \mathrm{mmol} / \mathrm{L}$, respectively. Postcalving, $18 \%$ of heifers had serum BHBA concentrations $>1.0 \mathrm{mmol} / \mathrm{L}$, and serum NEFA concentrations had median and upper quartile values of 0.64 and $0.94 \mathrm{mmol} / \mathrm{L}$, respectively. 
Table 2. Description of variables used in null and final path models of risk factors for peripartum mastitis in pasture-grazed New Zealand dairy heifers

\begin{tabular}{|c|c|c|c|c|c|c|}
\hline Variable & Minimum & $\begin{array}{c}\text { First } \\
\text { quartile }\end{array}$ & Median & $\begin{array}{l}\text { Third } \\
\text { quartile }\end{array}$ & Maximum & $\mathrm{n}$ \\
\hline \multicolumn{7}{|l|}{ Continuous measures ${ }^{1}$} \\
\hline \multicolumn{7}{|l|}{ Precalving } \\
\hline BHBA_PRE (mmol/L) & 0.30 & 0.60 & 0.70 & 0.90 & 4.70 & 708 \\
\hline NEFA_PRE (mmol/L) & 0.01 & 0.26 & 0.39 & 0.56 & 2.38 & 708 \\
\hline BCS_PRE & 4.5 & 5.5 & 6 & 6.5 & 7 & 708 \\
\hline SAMPLE_CALVE_DAYS & -9 & -30 & -39 & -50 & -127 & 697 \\
\hline \multicolumn{7}{|l|}{ Postcalving } \\
\hline BHBA_POST* (mmol/L) & 0.10 & 0.60 & 0.70 & 0.90 & 2.70 & 672 \\
\hline NEFA_POST* (mmol/L) & 0.07 & 0.42 & 0.64 & 0.94 & 2.18 & 672 \\
\hline BCS_POST & 3.5 & 5 & 5 & 5.5 & 6.5 & 662 \\
\hline BCS_CHANGE* & -2.5 & -1.5 & -1 & -0.5 & 1 & 662 \\
\hline MIN_HGT* (cm) & 39 & 49 & 52 & 55 & 66 & 654 \\
\hline \multirow[t]{2}{*}{ SAMPLE_CALVE_DAYS } & 0 & 1 & 2 & 3 & 5 & 665 \\
\hline & \multicolumn{6}{|c|}{ Proportion in each category } \\
\hline Categorical measures $^{2}$ & 1 & 2 & & & 4 & \\
\hline \multicolumn{7}{|l|}{ Precalving } \\
\hline TAIL_PRE & 0.038 & 0.027 & & 126 & 0.809 & 708 \\
\hline HYGIENE_PRE & 0.551 & 0.274 & & 088 & 0.087 & 704 \\
\hline \multicolumn{7}{|l|}{ Postcalving } \\
\hline TAIL_POST & 0.097 & 0.009 & & 627 & 0.267 & 663 \\
\hline HYGIENE_POST* & 0.366 & 0.385 & & 169 & 0.080 & 662 \\
\hline \multirow[t]{2}{*}{ Breed } & Friesian & Jersey & \multicolumn{2}{|c|}{ Other } & & \\
\hline & 0.411 & 0.302 & \multicolumn{2}{|c|}{0.287} & & 708 \\
\hline Dichotomous measures ${ }^{3}$ & Level & $\mathrm{n}$ & \multicolumn{2}{|c|}{ Denominator } & Incidence & \\
\hline PREBACTALL & Quarter & 502 & \multicolumn{2}{|c|}{2,710} & 0.185 & \\
\hline BHBA_POSTHI & Heifer & 121 & \multicolumn{2}{|c|}{672} & 0.180 & \\
\hline NEFA_POSTLO & Heifer & 223 & \multirow{2}{*}{\multicolumn{2}{|c|}{$\begin{array}{l}672 \\
654\end{array}$}} & 0.332 & \\
\hline MIN_HGTLO & Heifer & 361 & & & 0.552 & \\
\hline EDEMA & Heifer & 401 & \multicolumn{2}{|c|}{659} & 0.609 & \\
\hline LESION_POST & Quarter & 32 & \multicolumn{2}{|c|}{2,630} & 0.012 & \\
\hline BCS_LOS̄SHI & Heifer & 118 & \multicolumn{2}{|c|}{662} & 0.178 & \\
\hline HYGIENE_POSTPOOR & Heifer & 420 & \multicolumn{2}{|c|}{662} & 0.634 & \\
\hline CM0_14 & Quarter & 195 & \multicolumn{2}{|c|}{2,788} & 0.070 & \\
\hline SCM0_5 & Quarter & 473 & \multicolumn{2}{|c|}{2,644} & 0.179 & \\
\hline
\end{tabular}

${ }^{1}$ Continuous measures: BHBA PRE = precalving serum BHBA; NEFA PRE = precalving serum NEFA; BCS_PRE = precalving BCS; SAMPLE_CALVE_DAYS = day of sampling relative to calving (precalving negative, postcalving positive); BHBA_POST = postcalving serum BHBA; NEFA_POST = postcalving serum NEFA; BCS_POST = postcalving BCS; BCS_CHANGE = change in BCS over pre- to postcalving interval; MIN_HGT $=$ minimum height of front teats above ground .

${ }^{2}$ Categorical measures: TAIL_PRE $=$ precalving tail-length $(1=$ docked short, $2=$ docked long, $3=$ trimmed, 4 = untrimmed); HYGIENE_PRE = precalving udder hygiene ( 1 = clean, 2 = slightly dirty, 3 = moderately dirty, 4 = completely covered in dirt); TAIL_POST = postcalving tail-length; HYGIENE_POST = postcalving udder hygiene.

${ }^{3}$ Dichotomous measures: PREBACTALL = precalving IMI with any pathogen; BHBA_POSTHI = postcalving serum BHBA $>1.0 \mathrm{mmol} / \mathrm{L}$; NEFA_POSTLO = postcalving serum NEFA $<0.5 \mathrm{mmol} / \mathrm{L}$; MIN_HGTLO = minimum front teat height $<53 \mathrm{~cm}$ above ground; EDEMA = pitting edema of skin of caudal udder; LESION_POST $=$ lesion on teat skin or on teat orifice postcalving; BCS_LOSSHI $=$ loss of $>0.5$ BCS unit over peripartum period; HYGIENE_POSTPOOR = postcalving udder hygiene score $\geq 2$ (slightly dirty to completely covered in dirt or feces); CM0_14 = clinical mastitis on d 0 to 14 postcalving; SCM0_5 = subclinical mastitis on $\mathrm{d} 0$ to 5 postcalving.

*Variables used in dichotomous form in final regression models.

Direct associations (estimated as IRR from regression analysis of variables in the final model) are presented in Table 3 and are used in the final path model (Figure 2 ). The associations of precalving IMI with any pathogen with SCM0_5 and CM0_14 were the strongest of all measured variables (IRR $=3.3$ and 2.1, respectively). Postcalving serum NEFA $<0.5 \mathrm{mmol} / \mathrm{L}$ was associated with a relative increase in the risk of $\mathrm{CM}$ of $60 \%$ (i.e., $60 \%$ more cases of $\mathrm{CM}$ ) and postcalving serum BHBA $>1.0 \mathrm{mmol} / \mathrm{L}$ increased the risk of presence of pitting 


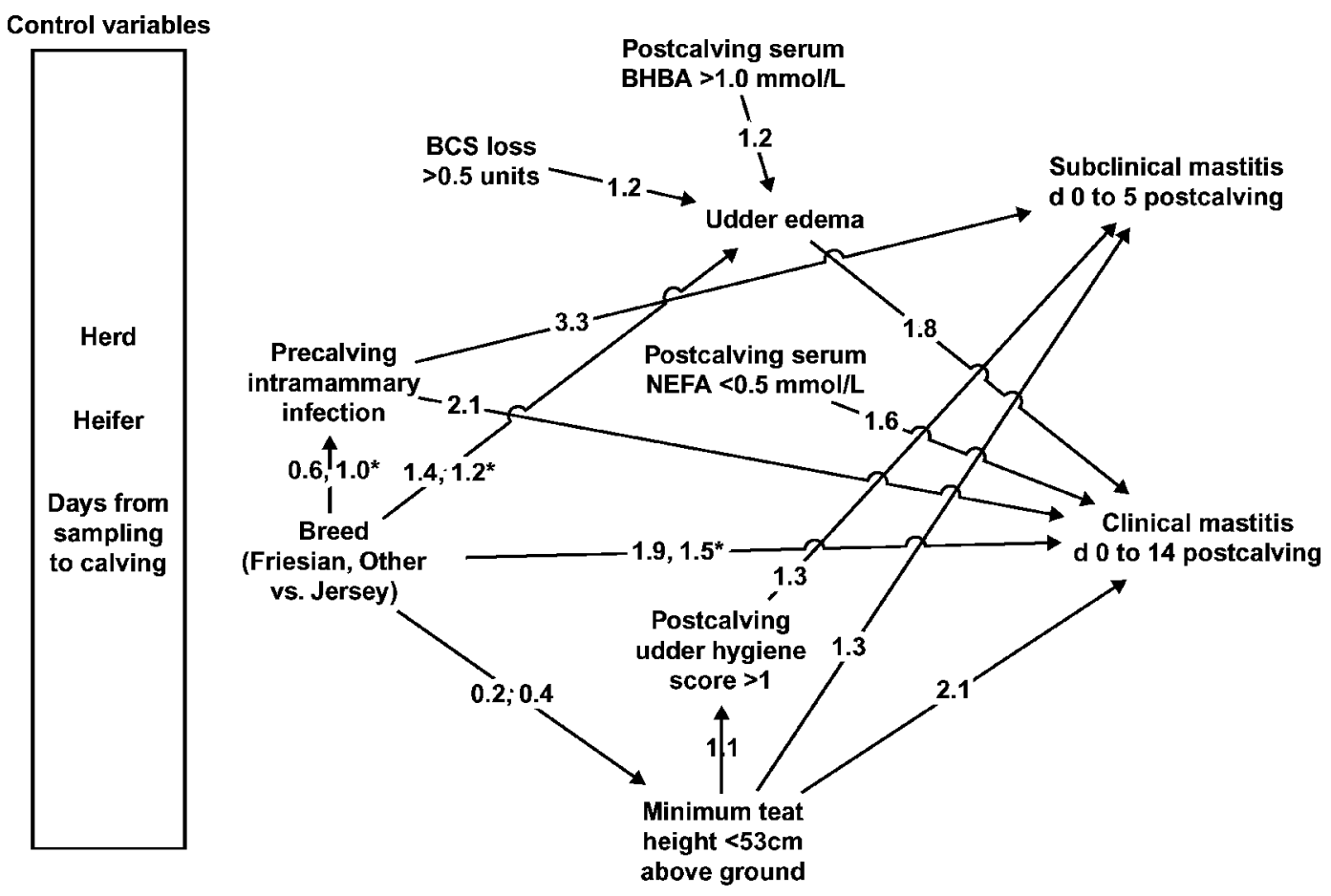

Figure 2. Final path model for significant risk factors for subclinical and clinical mastitis in pasture-grazed New Zealand dairy heifers. Control variables (boxed) were included in regression models to control for their confounding effects. *The coefficient for Other vs. Jersey was not significant.

edema in skin of caudal udder by $20 \%$. Risk of edema was increased $20 \%$ by heifers that lost $>0.5$ BCS units compared with those which lost $\leq 0.5$ BCS. Postcalving hygiene scores $>1$ increased the risk of quarters being diagnosed with SCM0_5 by 30\%, and heifers with minimum teat height less than the median had $30 \%$ and $110 \%$ increased risk of being diagnosed with SCM0_5 and CM0_14, respectively.

Population attributable fractions for the outcomes subclinical mastitis on d 0 to 5 postcalving and clinical mastitis on $\mathrm{d} 0$ to 14 postcalving are presented in Table 4. Presence of IMI in a quarter precalving had the largest PAF and smallest CI of variables for subclinical mastitis on $\mathrm{d} 0$ to 5 postcalving. Three risk factors for clinical mastitis on d 0 to 14 postcalving had similar PAF of approximately 30\% (udder edema, Friesian breed, and minimum teat height less than the median), but that for udder edema had the smallest CI.

\section{DISCUSSION}

In the current study, heifers lost a median of 1.0 BCS precalving. Precalving, $5 \%$ of heifers had subclinical ketosis (i.e., BHBA >1.4 mmol/L; Oetzel, 2004), 80\% had NEFA elevated above that normal for animals close to calving (i.e., NEFA $>0.4 \mathrm{mmol} / \mathrm{L}$; Oetzel, 2004), and $50 \%$ were in negative energy balance (i.e., NEFA $>0.7$ $\mathrm{mmol} / \mathrm{L}$; Adewuyi, et al., 2005). After calving, $<10 \%$ of heifers had subclinical ketosis, but $75 \%$ of heifers were in severe negative energy balance. Together, these results show that energy intake was deficient for the majority of these pasture-grazed heifers, and often severely so. The negative energy balance may have been because study heifers obtained most of their dietary intake from pasture that was in limited supply in late winter because of low growth rates, and feed was rationed to ensure availability later during lactation. Additionally, when heifers were cograzed with older cows, they may not have competed for limited feed as effectively as older age group cows.

Udder edema was common and an important risk factor for CM. The finding that udder edema in heifers increased CM cases by $80 \%$ supports Waage et al. (2001; teat and udder edema, odds ratios for $\mathrm{CM}=2.2$ and 1.65, respectively) and Slettbakk et al. (1995; odds ratio $=1.35$ ). A possible explanation for the association between edema and CM is that the condition impairs milk removal (Waage et al., 2001) with a reduction in the physical flushing effect, which results in sufficiently increased pathogen numbers to result in CM. In the current study, elevated BHBA concentrations and high BCS loss were associated with increased risk of udder edema and were indirectly associated with increased risk of CM. These associations would not have been 
Table 3. Description of regression models used in final path model of risk factors for peripartum mastitis in pasture-grazed New Zealand dairy heifers

\begin{tabular}{|c|c|c|c|c|c|c|c|c|}
\hline Dependent variable ${ }^{1}$ & Independent variable $^{1}$ & Coefficient & Error & $\mathrm{df}$ & $P$-value & $\mathrm{IRR}^{2}$ & $\mathrm{LCL}^{3}$ & $\mathrm{UCL}^{3}$ \\
\hline \multirow{2}{*}{ PREBACTALL } & BREED FRIESIAN & -0.46 & 0.16 & 664 & 0.01 & 0.63 & 0.46 & 0.87 \\
\hline & BREED OTHER & 0.05 & 0.17 & 664 & 0.77 & 1.05 & 0.75 & 1.46 \\
\hline \multirow[t]{3}{*}{ MIN_HGTLO } & (Intercept) & 2.06 & 0.29 & 631 & 0.00 & - & - & - \\
\hline & BREED FRIESIAN & -2.95 & 0.34 & 631 & 0.00 & 0.17 & 0.10 & 0.28 \\
\hline & BREED OTHER & -1.70 & 0.32 & 631 & 0.00 & 0.40 & 0.26 & 0.58 \\
\hline \multirow[t]{6}{*}{ EDEMA } & (Intercept) & -0.80 & 0.08 & 629 & 0.00 & - & - & - \\
\hline & BREED FRIESIAN & 0.30 & 0.08 & 629 & 0.00 & 1.35 & 1.15 & 1.59 \\
\hline & BREED OTHER & 0.18 & 0.09 & 629 & 0.06 & 1.20 & 1.00 & 1.43 \\
\hline & BCS_LOSSHI & 0.14 & 0.07 & 629 & 0.03 & 1.16 & 1.01 & 1.32 \\
\hline & BOH_POSTHI & 0.15 & 0.07 & 629 & 0.03 & 1.17 & 1.02 & 1.34 \\
\hline & SAMPLE_CALVE_DAYS & -0.11 & 0.02 & 627 & 0.00 & 0.90 & 0.86 & 0.94 \\
\hline \multirow[t]{7}{*}{ CM0-14 } & (Intercept) & -4.90 & 0.30 & 1,825 & 0.00 & - & - & - \\
\hline & PREBACTALL & 0.76 & 0.10 & 1,825 & 0.00 & 2.14 & 1.76 & 2.59 \\
\hline & NEFAPOST_LO & 0.44 & 0.18 & 612 & 0.02 & 1.55 & 1.08 & 2.22 \\
\hline & EDEMA & 0.59 & 0.19 & 612 & 0.00 & 1.81 & 1.26 & 2.60 \\
\hline & BREED FRIESIAN & 0.66 & 0.27 & 612 & 0.01 & 1.94 & 1.15 & 3.27 \\
\hline & BREED OTHER & 0.40 & 0.25 & 612 & 0.10 & 1.49 & 0.92 & 2.42 \\
\hline & MIN_HGTLO ${ }^{6}$ & 0.72 & 0.21 & 612 & 0.00 & 2.05 & 1.36 & 3.08 \\
\hline
\end{tabular}

${ }^{1}$ Dependent and independent variables: PREBACTALL = precalving IMI with any pathogen; MIN_HGTLO = minimum front teat height $<53 \mathrm{~cm}$ above ground; HYGIENE_ POSTPOOR = postcalving udder hygiene score $\geq 2$ (slightly dirty to completely covered in dirt or feces); EDEMA = pitting edema of skin of caudal udder; SCM0_5 = subclinical mastitis on d 0 to 5 postcalving; CM0_14 = clinical mastitis on d 0 to 14 postcalving; SAMPLE_CALVE_DAYS = day of sampling relative to calving (precalving negative, postcalving positive); BCS_LOSSHI = loss of $>0.5$ BCS unit over peripartum period; BOH_POSTHI = postcalving serum BHBA >1.0 mmol/L; NEFAPOST_LO = postcalving serum NEFA $<0.5 \mathrm{mmol} / \mathrm{L}$.

${ }^{2}$ Incidence risk ratio.

${ }^{3} \mathrm{LCL}$ and UCL are lower and upper 95\% confidence limits, respectively.

identified if ordinary logistic regression techniques on $\mathrm{CM}$ as the outcome were used, and demonstrate the value of path analysis techniques for exploring associations between antecedent variables. No association was found between high BCS loss and elevated BHBA concentrations. This lack of association may be due to varying intervals between heifers in the time from enrollment to calving, and the rate or timing of fat mobilization relative to calving, causing measurement error and failure to find associations truly present.

Data from this study showed an association between udder hygiene and environmental pathogen IMI postcalving with scores $\geq 2$ compared with score 1 . Udder hygiene was associated with the risk of environmental pathogen IMI in mixed-age cows (Schreiner and Ruegg, 2003). These authors found increased risk of IMI in cows with scores $>2$ compared with those $\leq 2$. We found a significant increase in udder contamination between pre- and postcalving measurement. This suggests that heifer management factors or behavior may differ between these periods. The finding of a small but positive association between udders of below mean minimum teat height and increased risk of poor udder hygiene might be explained by the reduced distance between the udder and the source of contamination (the ground) increasing the probability of contact by mud or water splash. Tail length of heifers was not associated with udder hygiene, in agreement with the findings of Schreiner and Ruegg (2002) in multiparous dairy cows. This reinforces the view that tail-docking to improve udder hygiene and health is not supported by scientific evidence.

The presence of teat-end lesions within $5 \mathrm{~d}$ of calving was not associated with subclinical mastitis or CM. The low prevalence of teat-end lesions and brief observation period meant low statistical power; however, because of the low prevalence of teat-end lesions, this condition is unlikely to have an important population impact on peripartum mastitis in heifers.

This study found increased risk of CM in Friesian compared with Jersey breed heifers (IRR $=2.2$ ), despite their lower prevalence of precalving IMI and greater 
Table 4. Estimates of population attributable fractions for risk factors for subclinical and clinical mastitis in pasture-grazed New Zealand dairy heifers ${ }^{1}$

\begin{tabular}{llccc}
\hline & & \multicolumn{3}{c}{$\begin{array}{c}\text { Population attributable } \\
\text { fraction }^{4}\end{array}$} \\
\cline { 3 - 5 } Disease $^{2}$ & Risk factor $^{3}$ & Estimate & LCL & UCL \\
\hline \multirow{2}{*}{ SCM0-5 } & PREBACTALL & 0.30 & 0.26 & 0.34 \\
& MIN_HGTLO & 0.15 & 0.03 & 0.25 \\
& HYGIENE_POSTPOOR & 0.17 & 0.06 & 0.27 \\
CM0-14 & PREBACTALL & 0.17 & 0.10 & 0.24 \\
& NEFAPOST_LO & 0.27 & 0.19 & 0.35 \\
& EDEMA & 0.33 & 0.15 & 0.47 \\
& BREED FRIESIAN & 0.28 & 0.07 & 0.44 \\
& MIN_HGTLO & 0.37 & 0.16 & 0.53 \\
\hline
\end{tabular}

1'Interpretation: 30\% (most likely value between 26 and 34\%) quarter cases of subclinical mastitis 0 to $5 \mathrm{~d}$ postcalving are associated with a precalving IMI with any pathogen.

${ }^{2}$ Diseases: SCM0_5 = subclinical mastitis on d 0 to 5 postcalving; CM0_14 = clinical mastitis on d 0 to 14 postcalving.

${ }^{3}$ Risk factors: PREBACTALL = precalving IMI with any pathogen; MIN_HGTLO $=$ minimum front teat height $<53 \mathrm{~cm}$ above ground; HYGIENE_POSTPOOR = postcalving udder hygiene score $\geq 2$ (slightly dirty to completely covered in dirt or feces); NEFAPOST_LO = postcalving serum NEFA $<0.5 \mathrm{mmol} / \mathrm{L}$; EDEMA = pitting edema of skin of caudal udder.

${ }^{4} \mathrm{LCL}$ and UCL are lower and upper 95\% confidence limits, respectively.

average minimum teat height. A Scandinavian study (Myllys and Rautala, 1995) found that the risk of CM ( $\pm 7 \mathrm{~d}$ of calving) was higher in Friesian compared with Ayrshire heifers (5.6 vs. 3.9\%, odds ratio $=1.6$ ). Friesian heifers were not at greater risk of subclinical mastitis, suggesting that immune response to IMI differs between breeds. Results suggest that heritability of heifer mastitis among Friesian cattle should be further evaluated to explore possible genetic causes for CM, and sires sought with offspring that have greater resistance to CM.

Precalving IMI and factors associated with it are important risk factors for postpartum subclinical mastitis or CM. Myllys (1995) found that quarters of heifers infected precalving had an increased risk of new IMI postcalving compared with previously IMI-free quarters, and Aarestrup and Jensen (1997) reported positive associations between pre- and postcalving IMI in heifers. In cows, the presence of a keratin "plug" in the teat canal is protective against new IMI over the nonlactating period (Dingwell et al., 2004), but prevalence of teat plugs in heifers before calving is unknown. Presence of precalving IMI may be associated with absence of a teat plug or lack of functional closure of the teat canal, permitting colonization of the gland with opportunist CNS bacteria from the teat skin leading to establishment of infection. Open teat canals or those without teat plug defense mechanisms may be at higher risk of IMI with both major and minor pathogens in the last few weeks of gestation. This would explain the observed increase in the risk of subclinical mastitis and CM postpartum when pathogens were isolated from the same quarter precalving. Precalving IMI with any pathogen had a stronger association with subclinical mastitis $(\operatorname{IRR}=3.3)$ than with $\mathrm{CM}(\mathrm{IRR}=2.1)$. This may be because only a small proportion of subclinical infections actually became clinical and that some cases of CM were not diagnosed by farmers, biasing the association toward the null.

An unexpected finding of this study was that high NEFA concentrations postcalving were protective of CM. Research suggests that increasing negative energy balance, as reflected in increasing serum NEFA concentrations, depresses immune function (Adewuyi et al., 2005) and increases susceptibility to CM. Nonetheless, in this study, the association was in the opposite direction, and no data were available to explain the result.

Estimates of PAF and their uncertainty as shown by width of CI may be used to guide intervention measures. Clinical mastitis is the primary concern of producers; hence, effective control measures need to be focused on preventing udder edema because it was among the highest PAF (Table 4). Precalving mastitis (or factors associated with it) has a high PAF because of its high prevalence and relatively high IRR for both $\mathrm{CM}$ and subclinical mastitis, and therefore should have a high priority in preventive strategies. Caution should be taken in generalizing PAF to other populations because they are based on estimates from the model, and the exposure distribution of the sample from which they are based. Still, in the absence of other data from the target population, these may serve as a guide for determining preventive measures.

There are several areas in which the epidemiology of peripartum mastitis in pasture-grazed heifers is inadequately understood. New knowledge is needed on factors affecting IMI in heifers from a month or more prepartum, as these infections are associated with the pattern of mastitis after calving. Risk factors for mastitis such as udder edema and milk leakage have been identified, but management factors affecting them need to be determined so that interventions at the group level can be applied. The results from this study suggest that exposure to environmental bacterial pathogens increased up to the time of calving and that physiological changes in the immediate precalving and calving period were associated with risk of mastitis. These changes need to be more precisely measured and their mechanisms defined, before robust preventive recommendations can be given.

\section{CONCLUSIONS}

Data presented suggest that important risk factors for postcalving subclinical mastitis and CM may be 
grouped into those affecting host immunity and exposure to environmental intramammary pathogens. Both groups of factors are amenable to management interventions, and provide opportunities to reduce the burden of mastitis in heifers. Control of the risk factors of poor udder hygiene, udder edema, and precalving IMI (through improved heifer management) most likely have the greatest impact on reducing postcalving mastitis in pasture-grazed dairy heifers.

\section{ACKNOWLEDGMENTS}

The authors are grateful to the 30 farmers and their staff who provided heifers and helped with sampling and data collection. Our thanks go to Animal Health Centre staff Fiona Anniss, Kathryn Berry, Rhonda Cooper, Elizabeth Blythe, Mike Kingstone, Shelley Roberts, Judith Forno, and Helena Habgood, who carried out the on-farm sample and data collection. We acknowledge funding for this study from Dairy Insight (Project 20017).

\section{REFERENCES}

Aarestrup, F. M., and N. E. Jensen. 1997. Prevalence and duration of intramammary infection in Danish heifers during the peripartum period. J. Dairy Sci. 80:307-312.

Adewuyi, A. A., E. Gruys, and F. J. van Eerdenburg. 2005. Nonesterified fatty acids (NEFA) in dairy cattle. A review. Vet. Q. $27: 117-126$.

Barkema, H. W., Y. H. Schukken, T. J. G. M. Lam, M. L. Beiboer, H. Wilmink, G. Benedictus, and A. Brand. 1998. Incidence of clinical mastitis in dairy herds grouped in three categories by bulk milk somatic cell counts. J. Dairy Sci. 81:411-419.

Barnouin, J., and M. Chassagne. 2001. Predictive variables for the occurrence of early clinical mastitis in primiparous Holstein cows under field conditions in France. Can. Vet. J. 42:47-53.

Borm, A. A., L. K. Fox, K. E. Leslie, J. S. Hogan, S. M. Andrew, K. M. Moyes, S. P. Oliver, Y. H. Schukken, D. D. Hancock, C. T. Gaskins, W. E. Owens, and C. Norman. 2006. Effects of prepartum intramammary antibiotic therapy on udder health, milk production, and reproductive performance in dairy heifers. J. Dairy Sci. 89:2090-2098.

Compton, C. W. R., C. Heuer, K. I. Parker, and S. McDougall. 2007. Epidemiology of mastitis in pasture-grazed dairy heifers and its effects on productivity. J. Dairy Sci. 90:4157-4170.

Curtis, C. R., M. D. Salman, D. Strickland, B. Edmonston, and H. N. Erb. 1988. Path-analysis using logistic-regression - interpretational and methodologic Issues. Acta Vet. Scand. Suppl. 84:469-472.

de Vliegher, S., H. Laevens, H. W. Barkema, I. R. Dohoo, H. Stryhn, G. Opsomer, and A. de Kruif. 2004. Management practices and heifer characteristics associated with early lactation somatic cell count of Belgian dairy heifers. J. Dairy Sci. 87:937-947.

Dingwell, R. T., K. E. Leslie, Y. Schukken, J. M. Sargeant, L. L. Timms, T. E. Duffield, G. P. Keefe, D. E. Kelton, K. D. Lissemore, and J. Conklin. 2004. Association of cow and quarter-level factors at drying-off with new intramammary infections during the dry period. Prev. Vet. Med. 63:75-89.

Dohoo, I., W. Martin, and H. Stryhn. 2003. Veterinary Epidemiologic Research. Atlantic Veterinary College Inc., Charlottetown, Canada.

Greenland, S. 2001. Estimation of population attributable fractions from fitted incidence ratios and exposure survey data, with an application to electromagnetic fields and childhood leukemia. Biometrics 57:182-188.

Hogan, J. S., R. N. Gonzalez, R. J. Harmon, S. C. Nickerson, S. P. Oliver, J. W. Pankey, and K. L. Smith. 1999. Laboratory Handbook on Bovine Mastitis. National Mastitis Council Inc., Madison, WI.

Macdonald, K., and J. Roche. 2004. Condition scoring made easy. Dexcel, Hamilton, New Zealand.

McDougall, S. 1998. Efficacy of two antibiotic treatments in curing clinical and subclinical mastitis in lactating dairy cows. N.Z. Vet. J. 46:226-232.

McNutt, L. A., C. Wu, X. Xue, and J. P. Hafner. 2003. Estimating the relative risk in cohort studies and clinical trials of common outcomes. Am. J. Epidemiol. 157:940-943.

Myllys, V. 1995. Staphylococci in heifer mastitis before and after parturition. J. Dairy Res. 62:51-60.

Myllys, V., and H. Rautala. 1995. Characterization of clinical mastitis in primiparous heifers. J. Dairy Sci. 78:538-545.

Oetzel, G. R. 2004. Monitoring and testing dairy herds for metabolic disease. Vet. Clin. North Am. Food Anim. Pract. 20:651-674.

Parker, K. I., C. Compton, F. M. Anniss, A. Weir, C. Heuer, and S. McDougall. 2007. Subclinical and clinical mastitis in heifers following the use of a teat sealant precalving. J. Dairy Sci. 90:207-218.

R Development Core Team. 2005. R: A language and environment for statistical computing. 2.2.0 ed. R Foundation for Statistical Computing, Vienna, Austria.

Schreiner, D. A., and P. L. Ruegg. 2002. Effects of tail docking on milk quality and cow cleanliness. J. Dairy Sci. 85:2503-2511.

Schreiner, D. A., and P. L. Ruegg. 2003. Relationship between udder and leg hygiene scores and subclinical mastitis. J. Dairy Sci. 86:3460-3465.

Slettbakk, T., A. Jorstad, T. B. Farver, and D. W. Hird. 1990. Impact of milking characteristics and teat morphology on somatic cell counts in first-lactation Norwegian cattle. Prev. Vet. Med. 8:253-267.

Slettbakk, T., A. Jorstad, T. B. Farver, and J. C. Holmes. 1995. Impact of milking characteristics and morphology of udder and teats on clinical mastitis in first- and second-lactation Norwegian cattle. Prev. Vet. Med. 24:235-244. doi:10.1016/0167-5877(95)00490-N

Suriyasathaporn, W., C. Heuer, E. N. Noordhuizen-Stassen, and Y. H. Schukken. 2000. Hyperketonemia and the impairment of udder defense: A review. Vet. Res. 31:397-412.

Trinidad, P., S. C. Nickerson, and T. K. Alley. 1990. Prevalence of intramammary infection and teat canal colonization in unbred and primigravid dairy heifers. J. Dairy Sci. 73:107-114.

Waage, S., S. A. Ødegaard, A. Lund, S. Brattgjerd, and T. Rothe. 2001. Case-control study of risk factors for clinical mastitis in postpartum dairy heifers. J. Dairy Sci. 84:392-399. 